\title{
PROFILE: CHRISTIAN WOLFF
}

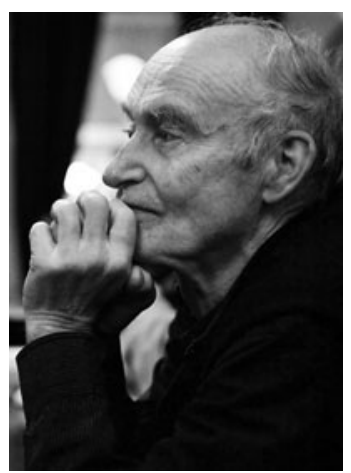

Christian Wolff (photo: Joseph F. Haefeli)

Christian Wolff (born in 1934, Nice, France) is a composer, teacher and sometime performer. Since 1941 he has lived in the United States. He studied piano with Grete Sultan and, briefly, composition with John Cage, in whose company, along with Morton Feldman, then David Tudor and Earle Brown, his work found inspiration and encouragement, as it did subsequently from association with Frederic Rzewski and Cornelius Cardew. $\mathrm{He}$ has also had a long association with Merce Cunningham and his dance company. As an improviser he has played with the English group AMM, Christian Marclay, Takehisa Kosugi, Steve Lacy, Larry Polansky, Keith Rowe, Kui Dong, Ikue Mori and Robyn Schulkowsky. Academically trained as a classicist, he has taught at Harvard and, from 1971 to 1999, in classics, comparative literature, and music at Dartmouth College.

Q. What is inspiring you at the moment?

A. Partly I have no idea, partly it's performers who would like new music to play, or whom I would like to have play, partly it's other music (a wide range, e.g. Buxtehude, Thelonious Monk), sometimes a poem by John Ashbery or Brecht, or the work of a visual artist, Jasper Johns, say, or Cy Twombly or Agnes Martin. 'At the moment' well, at this point in my life, the moment is increasingly informed by memories, so it's also a temporally discontinuous process, e.g. now in the Fall season in Vermont I might think of the sounds frogs make in the Spring, or the structural moves in a Merce Cunningham dance (the company dissolved almost two years ago). With music, more immediately, it's usually some detail, a texture, a violin in low register, a rhythmic phrase, a bit of tune in what I happen to be listening to.

Q. How has your compositional process evolved over the years?

A. I'll try a rough overview. The earliest music was determinately 'new', trying to start from scratch, inventing procedures, making a very abstract, stripped down music, explicitly notated, though there were some experiments in notating pitches indeterminately. Then there was indeterminacy, not in the compositional process but in the performing situation, which also involved new kinds of notation. This was variously elaborated in the direction of cueing systems whereby the performers play interdependently. A larger change happened in the later sixties, partly during a time in Britain when I was working with Cornelius Cardew, taking part in performances of his pieces 'notated' in prose description or visual designs, and improvising with AMM; also through encountering a new minimalism (early Terry 
Riley and Glass especially, then Reich) which then I found engaging and refreshing; and, thanks to my wife, hearing the rock music then emerging (the sixties!). I responded variously: systemic pieces like the Tilbury sequence, wider ranges of material and procedures including prose notation - for indeterminate use (e.g. in Burdocks), runs of melodic material for heterophonic performance, as in Exercises 1-14. Generally, I had an openness to melody, found (usually from folk music), referred to, and spontaneously emerging. Into this came my involvement with social and political issues (from the left) and trying to get that into the music. The music at this point looked and could sound a bit more like what was more conventionally regarded as 'music'. From the later eighties on it's been a mix of all of the above and trying still to find new technical procedures related to open performing situations, hoping always to find something new, which means for me lively and surprising, while not feeling arbitrary.

Q. What piece of art (of any media) has most affected your work? A. Well, no single piece of visual art. This question overlaps with the first ('what's inspiring me at the moment?'). Some pieces that have caught my attention and stuck in my head over the years: various Paul Klees, Giacometti's The Palace at 4 a.m. at MOMA in New York, almost anything by Jasper Johns, Van Gogh's Boots with Laces (there are several of these) which is actually the basis of a piece (with the Dutch title Schoenen met Vetters), Robert Rauschenberg's Rebus. Then there's poetry, early e.e. cummings; after that probably (the effects are often subliminal and unconscious, so partly I'm guessing) archaic Greek poetry and the language of Greek tragedy, with which I spent a lot of time over the years; more recently Hölderlin and John Ashbery. And there's Merce Cunningham, his dancing, choreography and the various dancers in his company.

Q. What does collaboration mean to you?

A. I'm all for it! In fact, I'd say I couldn't function musically without it (could anyone?). It means the inevitably social nature of musicmaking, from composing (which does start as a purely internal impulse, but who knows what helps shape that), to performing, to listening. There's a quite an intricate network there, with loops and feedbacks and radical indeterminacies, for example who knows exactly how someone will hear what another has played? More specifically for me it has meant the extraordinary good fortune of finding performers who know what to do with my music, who think of wonderful things to do with it, including things I hadn't thought of myself. Or who just play straight ahead, let the music be itself. I mention, among others, David Tudor, Frederic Rzewski, Robyn Schulkowsky (the exceptional virtuosi), also David Behrman, John Cage, Garrett List, Arthur Russell, Gordon Mumma, Cornelius Cardew, John Tilbury, Alvin Lucier, Malcolm Goldstein, Petr Kotik, Takehisa Kosugi, Keith Rowe, Eddie Prévost, Anton Lukoszevieze and his ensemble Apartment House, Larry Polansky, Michael Riessler, Joey Baron. And there are many more...

Q. What does 2014 hold for you, besides a significant birthday?! Is the future bright for new music? Would you do it all again?

A. Decades piling up (2014), what can I say? The process is inevitable, there's absolutely nothing you can do about it. I've often thought that if something is inevitable then let it be, don't worry about it, pay attention to what you are free to do. There'll be a kind of interchange 
with the inevitable. As far as composing (and performing) goes, now that I've really got the time for it (this has not regularly been the case throughout most of my life) I hope to carry on, partly because there are occasions for it and partly because I keep hoping that something new will turn up. Of course there's no guarantee of that and it can't be forced, but the hope keeps me going.

New music's future is murky to me. I'm discouraged by a general atmosphere of careerism, of primary striving for professional success, and by the institutions that foster this. On the other hand, I keep encountering (usually) younger people who are genuinely devoted simply to music, and who have an interest in the older movements of 'new' music and what has been vital in them. So, again, it's a matter of sustaining hope, however unlikely the circumstances. 'New' to me has come to mean something (in this case, musical) that represents and might help bring about - change in our social and political world; a long shot, but badly needed.

As for doing it all again: yes. No regrets. 